\title{
Evaluation of the apical extrusion of sodium hypochlorite gel in immature permanent teeth: An in vitro study
}

\section{Ocena przepchnięcia wierzchołkowego żelu z podchlorynem sodu w niedojrzałych zębach stałych - badanie in vitro}

\author{
Salma Fuad Al Nesser ${ }^{B-D}$, Nada George Bshara ${ }^{A, E, F}$ \\ Department of Pediatric Dentistry, Faculty of Dentistry, Damascus University, Syria \\ A - research concept and design; B - collection and/or assembly of data; $C$ - data analysis and interpretation; \\ $D$ - writing the article; $E$ - critical revision of the article; $F$ - final approval of the article
}

\section{Address for correspondence \\ Salma Fuad AI Nesser \\ E-mail: salma.alnesser93@gmail.com}

\section{Funding sources}

Damascus University, Syria

Conflict of interest

None declared

\section{Acknowledgements}

This study has been carried out at the Faculty of Dentistry of Damascus University, Syria, which deserves a great appreciation for all academic and financial support.

Received on November 21, 2018

Reviewed on January 21, 2019

Accepted on February 11, 2019

Published online on May 10, 2019

Cite as

Al Nesser SF, Bshara NG. Evaluation of the apical extrusion of sodium hypochlorite gel in immature permanent teeth: An in vitro study. DentMed Probl. 2019;56(2):149-153. doi:10.17219/dmp/103911

DOI

$10.17219 / \mathrm{dmp} / 103911$

Copyright

(C) 2019 by Wroclaw Medical University

This is an article distributed under the terms of the

Creative Commons Attribution 3.0 Unported License (CC BY 3.0)

(https://creativecommons.org/licenses/by/3.0/)

\begin{abstract}
Background. Sodium hypochlorite ( $\mathrm{NaOCl}$ gel has been suggested as a safer substitute in open apices as compared to solution, with the same antimicrobial effect.

Objectives. This study aimed to compare the amount of the apical extrusion of $\mathrm{NaOCl}$ gel and solution in immature permanent teeth.

Material and methods. A crossover in vitro study was conducted at the Department of Pediatric Dentistry, Faculty of Dentistry of Damascus University, Syria. Thirty freshly extracted immature single-rooted human premolars were decoronated and the cavity was then accessed. The teeth were radiographed to determine the mesiodistal dimension of the apex. In addition, the surface area of the apical foramen was calculated with Adobe Photoshop ${ }^{\circledR}$ to evaluate the amount of extrusion from the whole surface of the apex. The teeth were divided into 2 groups according to the size of the apex: $\leq 2.5 \mathrm{~mm}$ (group A) and $>2.5 \mathrm{~mm}$ (group B); each group was irrigated with $5 \mathrm{~mL}$ of NaOCl solution and 2 different commercial types of $\mathrm{NaOCl}$ gel for $60 \mathrm{~s}$, and then the extruded irrigant was measured in a plastic vial.

Results. The data was analyzed using the Kruskal-Wallis analysis. Based on the observed results, a statistically significant difference was noted $(p=0)$ between $\mathrm{NaOCl}$ solution and gel when the apical diameter was $\leq 2.5 \mathrm{~mm}$, while there was no significant difference between the 2 types of $\mathrm{NaOCl}$ gel. No statistically significant difference was observed $(p=0.2)$ between NaOCl solution and gel when the apical diameter was $>2.5 \mathrm{~mm}$.
\end{abstract}

Conclusions. Sodium hypochlorite gel is safer than solution when irrigating immature teeth with the apical diameter $\leq 2.5 \mathrm{~mm}$.

Key words: sodium hypochlorite, apical extrusion, immature teeth

Słowa kluczowe: podchloryn sodu, przepchnięcie wierzchołkowe, niedojrzałe zęby 


\section{Introduction}

Sodium hypochlorite $(\mathrm{NaOCl})$ is the most commonly used irrigant in endodontic treatment ${ }^{1}$; it has been considered the main endodontic irrigant due to its antimicrobial effect and its ability to dissolve the soft tissue and pulpal residuals in the root canal. ${ }^{2,3}$ However, the cytotoxic activity of $\mathrm{NaOCl}$ may cause acute injuries to the periapical area when the compound is extruded beyond the apex, causing hemolysis, ulcerations and the destruction of endothelial and fibroblast cells, resulting in emphysema, trismus and sensory-motor defects. ${ }^{4}$ About $42 \%$ of endodontic practitioners described at least 1 occurrence of $\mathrm{NaOCl}$ extrusion beyond the apex during their career. ${ }^{5}$

The amount of the extruded irrigant might be related to applying high pressure on the syringes, wedging the needle and the large size of the apex, which is observed more frequently in immature teeth. ${ }^{6}$

Endodontic treatment of immature permanent teeth with necrotic pulp or apical pathosis has always been a challenge, since mechanical instrumentation might result in further weakening of the dentinal walls of the canal, making it more difficult to obtain an apical seal. ${ }^{7}$

Currently, there is a shift in treating these teeth toward revascularization, which would allow root development to continue, and according to many case reports, this procedure has proved its success. ${ }^{8,9}$ The success is dependent on 3 factors, which are stem cells, growth factors and scaffolds. ${ }^{10}$

Disinfecting the canal is considered an important factor in this type of treatment. ${ }^{11}$

It has been found that the apical extrusion of $\mathrm{NaOCl}$ can harm the stem cells, affecting the success of this procedure. ${ }^{12}$ Hence, the aim of this study was to compare the extrusion of $\mathrm{NaOCl}$ solution and gel.

To the best of our knowledge, this is the first study to evaluate and compare the amount of extrusion between $\mathrm{NaOCl}$ solution and gel in immature permanent teeth.

\section{Material and methods}

A crossover in vitro study was conducted at the Department of Pediatric Dentistry, Faculty of Dentistry of Damascus University, Syria. The approval of the Scientific Research Committee was obtained before the initiation of the study. The sample size was calculated according to a prior pilot study using the $G^{*}$ Power software (v. 3.1) (Heinrich-Heine-Universität Düsseldorf, Germany; http://www.gpower.hhu.de/), and 30 single-rooted immature human premolars, freshly extracted due to orthodontic treatment, were used as the total specimen.

The criteria for tooth selection were as follows: lack of internal or external resorption as well as of visible caries, fractures or cracks under a stereoscopic microscope (Meiji Techno Co., Ltd., Saitama, Japan) at $\times 2$ magnification.
The teeth were cleaned with the CK-6 hand scaler instrument (Zeffiro-Lascod, Florence, Italy) to remove the soft tissue residual and were stored in plastic containers with $0.5 \%$ chloramine $\mathrm{T}$ for 1 week, and then moved to other containers filled with $0.9 \%$ saline and stored in a refrigerator at the temperature of $4^{\circ} \mathrm{C}$ until used.

\section{Preparation of specimens}

Conventional access cavity preparation was done using a 2-millimeter round bur and the roof of the pulp was removed with the Endo- $Z^{\circledR}$ bur (Dentsply, Ballaigues, Switzerland). Then, the pulp was removed using barbed broaches (VDW GmbH, Munich, Germany).

The teeth were decoronated to standardize the tooth length to $15 \mathrm{~mm}$ and the measurements were done using a digital caliper.

The teeth were covered with 2 layers of nail polish to seal the roots.

\section{Determining the dimensions of the apical foramen}

The surface area of the apices was measured using Adobe Photoshop ${ }^{\circledR}$ CC 2013 (Adobe Systems, Inc., San Jose, USA; www.adobe.com) by capturing the apex with a digital camera (Samsung NX500; Samsung, San Jose, USA) under a stereomicroscope (Meiji Techno Co., Ltd.) at $\times 2$ magnification. An endodontic ruler was set beside the foramen to calibrate the pixels by measuring the logical length of each $1 \mathrm{~mm}$ in pixels (Fig. 1). The borders of the apical foramen were selected with a pen tool and the surface area in $\mathrm{mm}^{2}$ was calculated from the measurement log after setting the measurement scale of the length in pixels according to the logical length of $1 \mathrm{~mm}$ (Fig. 2).

The teeth were inserted in a putty condensation silicone (ZetaPlus $^{\circledR}$; Zhermack GmbH, Marl, Germany) (Fig. 3) and radiographed in mesiodistal and buccolingual directions (imaging systems by Vatech Co., Ltd., Hwaseong,

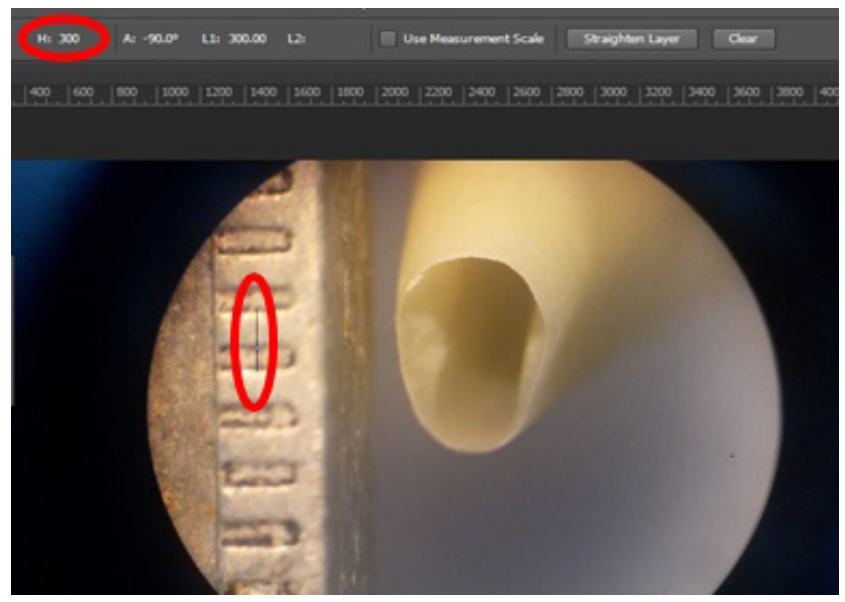

Fig. 1. Logical length of $1 \mathrm{~mm}=300$ pixels 


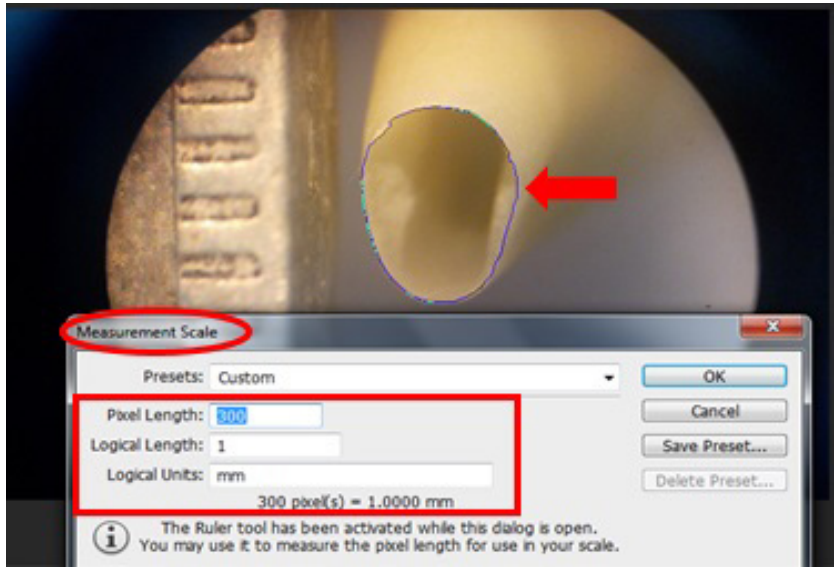

Fig. 2. Selecting the borders of the apical foramen and setting the logical length of each $1 \mathrm{~mm}$ to 300 pixels

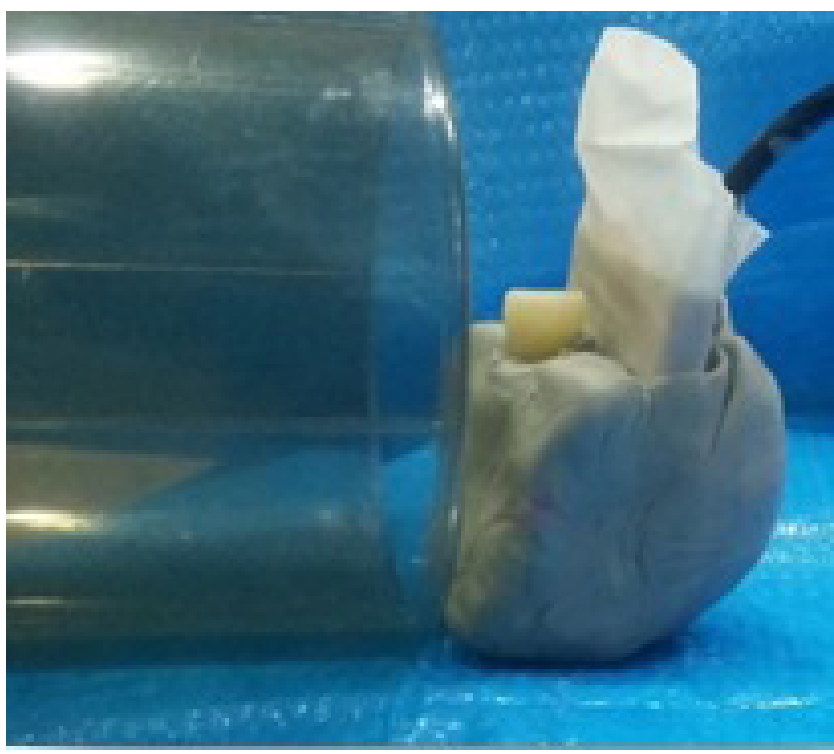

Fig. 3. Securing teeth in putty silicone before radiography

South Korea, and de Götzen ${ }^{\circledR}$ S.r.l., Olgiate Olona, Italy) to ensure that the canals are straight $\left(<5^{\circ}\right)$ according to Schneider ${ }^{13}$ and to determine the mesiodistal dimension of the apices in order to make clinical simulation.

\section{Study groups and irrigation protocol}

The teeth were then divided into 2 groups:

- group A: teeth with radiographically confirmed apical diameter $\leq 2.5 \mathrm{~mm}$ (surface area $\leq 6.9 \mathrm{~mm}^{2}$ );

- group B: teeth with radiographically confirmed apical diameter $>2.5 \mathrm{~mm}$ (surface area $>6.9 \mathrm{~mm}^{2}$ ).

The teeth in each group were irrigated with $5 \mathrm{~mL}$ of

3 different irrigants:

- $\mathrm{NaOCl}$ solution 5.25\% $\left(\right.$ Carmel $^{\circledR}$; Akka Brothers Co. Carmel Detergent, Damascus, Syria);

- $\mathrm{NaOCl}$ gel 2.25\% (Harpic ${ }^{\circledR}$; Reckitt Benckiser, PLC, Slough, UK);

- $\mathrm{NaOCl}$ gel 2.25\% (WC Net Bleach ${ }^{\circledR}$; Bolton Manitoba, Milan, Italy).
After each irrigation, the teeth were washed with $5 \mathrm{~mL}$ of saline and dried using paper points.

The irrigation was done with a 27-gauge side vent needle (Endo-Top; CERKAMED, Stalowa Wola, Poland), placed at $3 \mathrm{~mm}$ of the working length by adding a rubber stopper to the needle.

The irrigation protocol was employed according to the Institutional Review Board of the Oregon Health \& Science University (Portland, USA) as the final irrigation; the flow rate was $5 \mathrm{~mL} / 60 \mathrm{~s}$ with $30 \mathrm{~s}$ of irrigation and $60 \mathrm{~s}$ of waiting, ${ }^{14}$ a vertical movement with the needle was done 1-2 mm away from the apex every $6 \mathrm{~s}$.

\section{Collecting the extruded irrigants}

The Myers and Montgomery model was used in this study (Fig. 4). ${ }^{15} \mathrm{~A}$ hole was made in the center of a plastic lid, and the teeth were inserted up to the level of the cementoenamel junction and fixed to the vial with a composite (Tetric N-Ceram ${ }^{\circledR}$; Ivoclar Vivadent, Zurich, Switzerland). A 22-gauge needle was bent and inserted into the lid to equalize the air pressure inside and outside the plastic vial.

An empty plastic container was weighed using a 0.01-gram balance weight. Then, $5 \mathrm{~mL}$ of each irrigant was placed in the weighed container and the weight of the irrigant was calculated by subtracting the weight of the empty plastic container. The irrigant extruded after the irrigation was measured in the same way as previously described. The container was replaced with a new one after each irrigation.

The weights $[\mathrm{g}]$ of the extruded irrigants were transformed to volumes $[\mathrm{mL}]$ using the following equation:

$$
\text { volume of extruded irrigant }=\frac{\text { weight of extruded irrigant } \times 5}{\text { weight of } 5 \mathrm{~mL} \text { of irrigant }}
$$

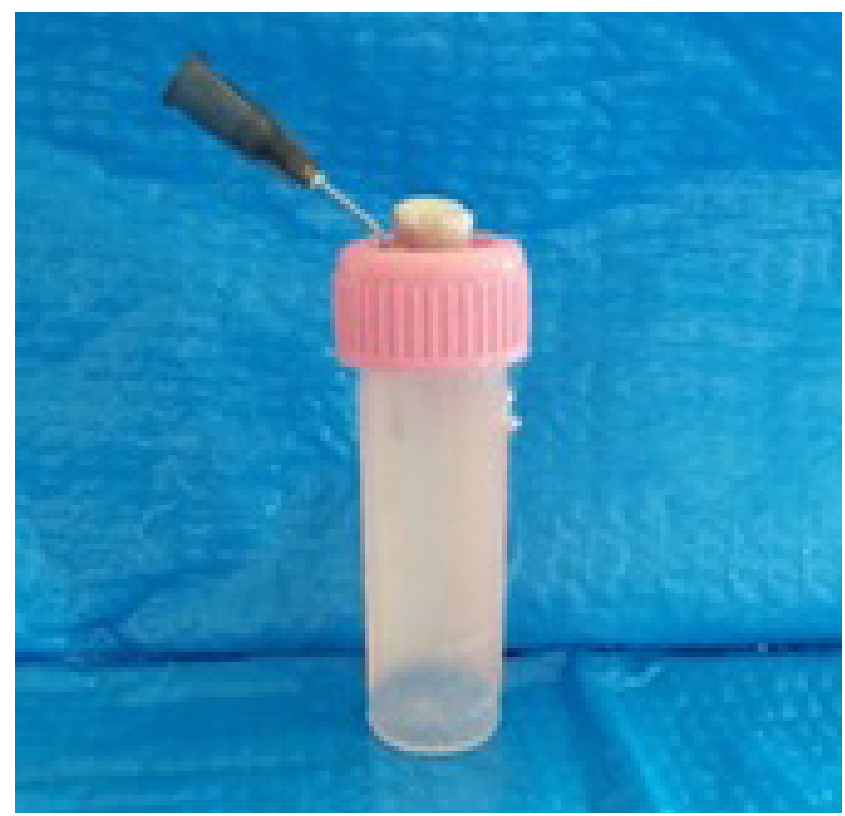

Fig. 4. The Myers and Montgomery model 


\section{Test of viscosity}

Kinematic viscosity was measured by determining the time it took each irrigant to flow in a glass capillary U-tube (CANNON-Fenske ${ }^{\circledR}$ and CANNON-Ubbelohde ${ }^{\circledR}$; CANNON Instrument Company, State College, USA) inserted into a room temperature viscometer bath (JP SELECTA, Abrera, Barcelona, Spain), and multiplying this time by the calibration constant of the specific tube.

\section{Statistical analysis}

The normality of the data was checked using the Kolmogorov-Smirnov test, and the Kruskal-Wallis test was used to determine if there was a statistically significant difference in the volume of the apically extruded irrigants between group A and group B.

In this study, the level of significance ( $p$-value) was set at 0.05 and the statistical analysis was performed using the IBM SPSS software v. 23 (IBM Corp., Armonk, USA). Descriptive statistics, including minimum and maximum, means, and standard deviations $(S D)$ were also calculated.

\section{Results}

The minimum and maximum, mean, and $S D$ results of $\mathrm{NaOCl}$ viscosity are shown in Table 1 . Sodium hypochlorite gel Harpic has shown the highest viscosity, followed by $\mathrm{NaOCl}$ gel WC Net Bleach and $\mathrm{NaOCl}$ solution (Carmel).

The extrusion volumes were statistically significantly different between the 3 types of irrigants in group A (apex $\leq 2.5 \mathrm{~mm})(p=0.000)$ (Table 2$)$. Sodium hypochlorite solution (Carmel) had the highest amount of extrusion, followed by $\mathrm{NaOCl}$ gel WC Net Bleach, and the least amount was noted for $\mathrm{NaOCl}$ gel Harpic.

Table 1. Descriptive results of the viscosity test [cSt]

\begin{tabular}{|l|c|c|c|}
\multicolumn{1}{|c|}{ Type of irrigant } & Min & Max & Mean \pm SD \\
\hline $\mathrm{NaOCl}$ solution Carmel & 0.56 & 0.57 & $0.563 \pm 0.004$ \\
$\mathrm{NaOCl}$ gel Harpic & 225 & 227.5 & $226.666 \pm 1.29$ \\
$\mathrm{NaOCl}$ gel WC Net Bleach & 177.5 & 197.5 & $190 \pm 9.746$ \\
\hline
\end{tabular}

SD - standard deviation.
The pairwise comparison test showed that $\mathrm{NaOCl}$ solution (Carmel) had a significantly higher amount of extrusion than $\mathrm{NaOCl}$ gel WC Net Bleach $(p=0.000)$ and Harpic $(p=0.000)$, and it also revealed that there was no statistically significant difference between $\mathrm{NaOCl}$ gel WC Net Bleach and Harpic $(p=0.813)$ (Table 3).

The extrusion volumes were not statistically significantly different between the 3 types of irrigants in group B (apex $>2.5 \mathrm{~mm})(p=0.214)$ (Table 2).

Table 3. Pairwise comparison between the 3 types of irrigants in group $A[\mathrm{~mL}]$

\begin{tabular}{|l|c|c|c|}
\hline \multicolumn{1}{|c|}{ Comparison } & $\begin{array}{c}\text { Difference } \\
\text { of means }\end{array}$ & SE & $p$-value \\
\hline $\begin{array}{l}\mathrm{NaOCl} \text { gel Harpic } \\
\text { vs NaOCl gel WC Net Bleach }\end{array}$ & -1.133 & 4.794 & 0.813 \\
$\begin{array}{l}\mathrm{NaOCl} \text { solution Carmel } \\
\text { vs NaOCl gel Harpic }\end{array}$ & 19.667 & 4.794 & 0.000 \\
$\begin{array}{l}\mathrm{NaOCl} \text { solution Carmel } \\
\text { vs NaOCl gel WC Net Bleach }\end{array}$ & 18.533 & 4.794 & 0.000 \\
\hline
\end{tabular}

SE - standard error.

\section{Discussion}

The purpose of this study was to compare the amount of the extrusion of $\mathrm{NaOCl}$ solution and gel. Many studies have compared the amount of the extrusion of $\mathrm{NaOCl}$ solution with different irrigating systems. However, the studies have been limited to mature permanent teeth and few studies have modified mature teeth to resemble immature teeth. ${ }^{16,17}$

In this study, real freshly extracted immature premolars with different apical diameters were used to simulate the actual clinical situation.

Sodium hypochlorite gel was chosen, because no studies have evaluated the amount of its extrusion beyond the apex. Also, research showed its effectiveness as an intracanal irrigant; Al-Sudani and Al Omar proved its efficacy in removing the smear layer at $2.5 \%$ concentration compared to $\mathrm{NaOCl}$ solution at the same concentration. ${ }^{18}$ This result was consistent with the study done by Zand et al., who observed no significant difference between 2.5\% $\mathrm{NaOCl}$ gel and solution in smear layer removal. ${ }^{19}$ Furthermore, Nejad Shamsi et al. reported the same effect of $\mathrm{NaOCl}$ gel on the growth of E. faecalis as in the case of $\mathrm{NaOCl}$ solution at the same concentration, thus considering it safe as an intracanal irrigant. ${ }^{20}$

Table 2. Descriptive results of the Kruskal-Wallis test regarding the amount of extrusion [mL]

\begin{tabular}{|c|c|c|c|c|c|}
\hline Group & Type of irrigant & Min & Max & Mean $\pm S D$ & $p$-value \\
\hline \multirow{3}{*}{ A } & $\mathrm{NaOCl}$ solution Carmel & 4.73 & 4.99 & $4.82 \pm 0.05$ & \multirow{3}{*}{$0.000^{*}$} \\
\hline & $\mathrm{NaOCl}$ gel Harpic & 0.86 & 4.99 & $4.02 \pm 1.07$ & \\
\hline & $\mathrm{NaOCl}$ gel WC Net Bleach & 1.31 & 4.86 & $4.15 \pm 0.89$ & \\
\hline \multirow{3}{*}{ B } & $\mathrm{NaOCl}$ solution Carmel & 4.72 & 4.99 & $4.83 \pm 0.07$ & \multirow{3}{*}{0.214} \\
\hline & $\mathrm{NaOCl}$ gel Harpic & 3.06 & 4.99 & $4.57 \pm 0.48$ & \\
\hline & $\mathrm{NaOCI}$ gel WC Net Bleach & 3.81 & 4.93 & $4.71 \pm 0.31$ & \\
\hline
\end{tabular}

group A: apical diameter $\leq 2.5$ mm; group B: apical diameter $>2.5 \mathrm{~mm}$; * statistically significant. 
In this study, 2 different types of commercial $\mathrm{NaOCl}$ gel were selected, as the manufacturers always keep the additional materials added secret.

Nail varnish was used to seal the root and prevent the leakage from the lateral root canals.

Arora and Tewari found that the apical foramen would have an oval, triangular, kidney, or irregular forms. ${ }^{21}$ For this reason, the surface area was calculated using Adobe Photoshop to evaluate the amount of apical extrusion from the whole surface of the apical foramen, regardless of its pattern and shape, and then the mesiodistal diameter was measured radiographically to obtain the results similar to the clinical situation.

A side vent needle was chosen, as it can move the irrigant sideways and reduce the extrusion. ${ }^{22}$

Despite the difference in viscosity between $\mathrm{NaOCl}$ gel and solution, the pressure applied on the plunger of the syringe would also be different; therefore, the flow rate was standardized to be $5 \mathrm{~mL} / 60 \mathrm{~s}$ in all the specimens. Up-and-down movements were done every $6 \mathrm{~s}$ to evoke agitation. $^{22}$

This study showed significantly less extrusion of $\mathrm{NaOCl}$ gel compared to solution in group $\mathrm{A}$, where the apical diameter was less than $2.5 \mathrm{~mm}$; this reduction took place despite the higher pressure applied on the plunger of the syringe when irrigating with the gel form as compared to solution at the same flow rate.

Although the results of this study showed that the mean value of apical extrusion of $\mathrm{NaOCl}$ gel in group $\mathrm{A}$ was high $(4 \mathrm{~mL})$, and this could be referred to the extremely immature teeth used in this study, it is thought that $\mathrm{NaOCl}$ gel could dissolve soft tissues to a lesser extent than solution.

The results also showed no statistically significant difference between the 2 types of $\mathrm{NaOCl}$ gel. These results were consistent with the results of the viscosity test, as the viscosity of $\mathrm{NaOCl}$ gel was $226.666 \mathrm{cSt}$ for Harpic and 190 cSTt for WC Net Bleach, while the least viscosity was observed in the case of $\mathrm{NaOCl}$ solution (0.563 cSt).

Moreover, group B showed no statistically significant difference between $\mathrm{NaOCl}$ gel and solution, which indicates that all the irrigants would extrude apically when the dimensions are large enough.

\section{Conclusions}

Sodium hypochlorite solution cannot be used as an intracanal irrigant in immature teeth because of the high risk of apical extrusion.

\section{ORCID iDs}

Salma Fuad Al Nesser (D) https://orcid.org/0000-0002-9492-3599 Nada George Bshara (D) https://orcid.org/0000-0003-0055-6204

\section{References}

1. Wright PP, Walsh LJ. Optimizing antimicrobial agents in endodontics. In: Kumavath RN, ed. Antimicrobial Agents. Croatia: InTech; 2017:87-107.

2. Rahimi S, Janani M, Lotfi $M$, et al. A review of antibacterial agents in endodontic treatment. Iran Endod J. 2014;9(3):161-168.

3. Mohammadi Z. Sodium hypochlorite in endodontics: An update review. Int Dent J. 2008;58(6):329-341.

4. Guivarc'h M, Ordioni U, Ahmed HM, Cohen S, Catherine JH, Bukiet F. Sodium hypochlorite accident: A systematic review. J Endod. 2017;43(1):16-24.

5. Kleier DJ, Averbach RE, Mehdipour O. The sodium hypochlorite accident: Experience of diplomates of the American Board of Endodontics. J Endod. 2008;34(11):1346-1350.

6. Mathew ST. Risks and management of sodium hypochlorite in endodontics. J Oral Hyg Heal. 2015;3(3):3-7.

7. Wigler R, Kaufman AY, Lin S, Steinbock N, Hazan-Molina H, Torneck CD. Revascularization: A treatment for permanent teeth with necrotic pulp and incomplete root development. J Endod. 2013;39(3):319-326.

8. da Silva Limoeiro AG, dos Santos AHB, Kato AS, Freire LG, da Silveira Bueno CE. Pulp revascularization: A case report [in Portuguese]. Dent Press Endod. 2015;5(2):74-77.

9. Saeki K, Fujita Y, Shiono Y, Morimoto Y, Maki K. Pulp revascularization in immature permanent tooth with apical periodontitis using mineral trioxide aggregate. Case Rep Med. 2014;2014:564908.

10. Namour M, Theys S. Pulp revascularization of immature permanent teeth: A review of the literature and a proposal of a new clinical protocol. ScientificWorldJournal. 2014;2014:737503.

11. He L, Zhong J, Gong Q, et al. Treatment of necrotic teeth by apical revascularization: Meta-analysis. Sci Rep. 2017;7(1):13941.

12. Martin DE, de Almeida JF, Henry MA, et al. Concentration-dependent effect of sodium hypochlorite on stem cells of apical papilla survival and differentiation. J Endod. 2014;40(1):51-55.

13. Balani $P$, Niazi $F$, Rashid $H$. A brief review of the methods used to determine the curvature of root canals. J Res Dent. 2015;3:57-63.

14. Nielsen BA, Craig Baumgartner J. Comparison of the EndoVac System to needle irrigation of root canals. J Endod. 2007;33(5):611-615.

15. Myers GL, Montgomery S. A comparison of weights of debris extruded apically by conventional filing and canal master techniques. J Endod. 1991;17(6):275-279.

16. Aksel H, Askerbeyli S, Cigdem C, Serper A. Effect of needle insertion depth and apical diameter on irrigant extrusion in simulated immature permanent teeth. Braz Oral Res. 2014;28(1):1-6.

17. Velmurugan $N$, Sooriaprakas $C$, Jain $P$. Apical extrusion of irrigants in immature permanent teeth by using EndoVac and needle irrigation: An in vitro study. J Dent (Tehran). 2014;11(4):433-439.

18. Al-Sudani DA, Al Omar HA. Evaluation of sodium hypochlorite $(\mathrm{NaOCl})$ gel as an endodontic irrigant. J Biomater Tissue Eng. 2011;1(2):215-218.

19. Zand V, Lotfi M, Soroush MH, Abdollahi AA, Sadeghi M, Mojadadi A. Antibacterial efficacy of different concentrations of sodium hypochlorite gel and solution on Enterococcus faecalis biofilm. Iran Endod J. 2016;11(4):315-319.

20. Nejad Shamsi P, Atash Biz Yeganeh L, Vadiati Saberi B, Forghan Parast K, Taghavi Kashan A. Antibacterial effect of sodium hypochlorite gel and solution on Enterococcus faecalis. 3DJ. 2017;6(1):27-30.

21. Arora S, Tewari S. The morphology of the apical foramen in posterior teeth in a North Indian population. Int Endod J. 2009:42(10):930-939.

22. Jena A, Sahoo SK, Govind S. Root canal irrigants: A review of their interactions, benefits, and limitations. Compend Contin Educ Dent. 2015;36(4):256-261. 